\title{
Constitutive Equations for a Simulator of Airlift Pump in a Large Diameter Pipe using Drift-Flux Model
}

\author{
by Nobuo HATAKEYAMA ${ }^{\mathrm{a}}$, Yoshiyuki SHIMIZU ${ }^{\mathrm{b}}$ and Tadashi MASUYAMA ${ }^{\mathrm{c}}$
}

a. Ex-prof., Ichinoseki National College of Technology

(Corresponding author, E-mail: hatake@my.email.ne.jp)

b. Prof., School of Marine Science and Technology, Tokai University

c. Ex-prof., School of Marine Science and Technology, Tokai University

One of the authors has developed a numerical simulator of airlift pump to solve governing equations represented by the drift flux model. The solver is based on the finite volume method which is known as SIMPLER algorithm for numerical scheme. The calculated results using the simulator were comparatively in good agreement with experimental ones by Weber et al. and Saito et al., despite lack of appropriate correlations used in the constitutive equations.

In this study, the simulator is improved by a recent study (Ishii and Hibiki, 2011) on the constitutive equations of the drift flux model in the gas-liquid two-phase flow. The effect of newly incorporated correlations versus original ones in the constitutive equations is studied on the lifting characteristics such as relation between inputting air and lifted water. Also, flow characteristics along axial direction of pipes are examined to compare numerical results with experimental ones over wide range of pipe diameter and pipe length. Furthermore, pressure losses are grasped from the standpoint of the pump head, the relation between various pressure losses and lifting characteristics is discussed.

KEY WORDS: Large Diameter Pipe, Airlift Pump, Drift-Flux Model, Constitutive Equation, Numerical Simulation, Gas-Liquid Two Phase Flow

1.はじめに

新たな海洋基本計画が平成 25 年 4 月に閣議決定され，「海洋エ ネルギー・鉱物資源開発計画」が改定された ${ }^{1)}$ 。鉱物資源開発 については海底熱水鉱床，コバルトリッチクラフト，マンガン団 塊ならびにレアアース堆積物の採鉱・揚鉱技術を確立するとされ ている。

さて, 著者らの 1 人は, 既に, マンガン団塊などの深海底鉱物 資源をエアリフトポンプによって揚鉱するために，一次元ドリ フトフラックスモデルによる基礎方程式 ${ }^{2,3)}$ を SIMPLER 法 ${ }^{4)}$ に よって数值計算するシミュレーターを開発している ${ }^{5-7)}$ 。シミュ レーターの検証を Weber $ら^{8)}$ および斎藤ら ${ }^{9)}$ による比較的大口 径管を用いたエアリフトポンプ実験結果と比較することによって 行い，比較的良好な結果を得ている ${ }^{5-7)}$ 。その際，数值計算にお ける格子分割数および非定常計算における時間刻みの影響につい ても検討している。これらのことを踏まえ，深海底鉱物揚鉱用工 アリフトポンプを設計および運転するための基礎資料を提供する ため, $5,000 \mathrm{~m}$ 級エアリフトポンプについてシミュレーションを 行い，揚水・揚鉱特性に及ぼす構成方程式の相関式に関わる係数

*2017 年 9 月 21 日受付 2017 年 12 月 1 日受理

1. 正会員 元一関工業高等専門学校 教授

2. 正会員 東海大学教授海洋学部

3. 正会員 元東海大学 海洋学部教授

[ 著者連絡先 ] E-mail: hatake@my.email.ne.jp

キーワード : 大口径管，エアリフトポンプ，ドリフトフラックスモデル，構成方 程式, 数值シミュレーション, 気液二相流
等の影響について検討 ${ }^{10)} し$, さらに拡大揚鉱管・背圧装置を用 いた流動特性 ${ }^{11)}$ ，送気および揚鉱開始・停止特性等 ${ }^{12,13)}$ につ いて検討した。

なお, シミュレーターを開発した時点では, 大口径管に対する ドリフトフラックスモデルの構成方程式に関わる相関式は整理さ

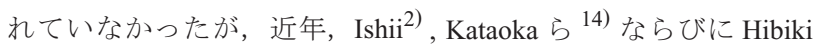
ら 15,16) の研究結果を踏まえて, Ishii-Hibiki によって著書 ${ }^{17)}$ に まとめられている。特に大口径管においては, スラグ気泡は界面 の不安定性によって持続せず，球冠状気泡 (cap bubble) に崩壊す ることが指摘されており，それに対するドリフト速度の相関式が 提示されている。

本研究は, 先に著者らが開発したエアリフトシミュレーターに ドリフトフラックスモデルの構成方程式に関わる近年の研究結果 を取り込むと共に, 以前に用いた相関式と対比しながら，それら が揚水特性（送気量に対する揚水量との関係）に及ぼす影響につ いて検討したものである。また，管径および管長の広い範囲の既 往の実験結果 $\left.{ }^{8}, 9,18-20\right)$ と数值計算結果とを比較すると共に, 数 值計算によって得られた流動方向の分布等について詳細に検討し た。さらにポンプの揚程という観点から圧力損失を捉え, 諸損失 の比率および揚水特性との関わりについて考察した。

\section{2. 支配方程式および数值解法}

\section{$2 \cdot 1$ 基礎方程式}

エアリフト管内の流動状態は, 等温であり, かつ相変化がない と仮定する。混合体モデルの一つであるドリフトフラックスモデ 
ル2,17) に基づく質量および運動量保存式は，次のように表される。 混合体の質量保存式 :

$\frac{\partial \rho_{M}}{\partial t}+\frac{\partial}{\partial z}\left(\rho_{M} V_{M}\right)=0$

混合体の運動量保存式 :

$\frac{\partial}{\partial t}\left(\rho_{M} V_{M}\right)+\frac{\partial}{\partial z}\left(\rho_{M} V_{M}^{2}\right)$

$=-\frac{\partial P}{\partial z}-\frac{4 \tau_{W}}{D}-\rho_{M} g \cos \theta-\frac{\partial}{\partial z}\left(\frac{f_{G} \rho_{G} \rho_{L}}{f_{L} \rho_{M}} V_{G j}^{* 2}\right)$

気相の質量保存式 :

$\frac{\partial}{\partial t}\left(f_{G} \rho_{G}\right)+\frac{\partial}{\partial z}\left(f_{G} \rho_{G} V_{M}\right)=\left(\Gamma_{G}\right)_{a i}-\frac{\partial}{\partial z}\left(\frac{f_{G} \rho_{G} \rho_{L}}{\rho_{M}} V_{G j}^{*}\right) \ldots$

ここに, $\left(\Gamma_{G}\right)_{a i}$ は単位体積当たりの送気質量流量であり, 混合 体の平均密度 $\rho_{M}$, 質量中心速度 $V_{M}$ および気相の平均ドリフト 速度 $V_{G j}^{*}$ は，それぞれ次式によって定義される。

$$
\begin{aligned}
& \rho_{M}=f_{G} \rho_{G}+f_{L} \rho_{L} \\
& f_{G}+f_{L}=1 \ldots \ldots \ldots \ldots \ldots \ldots \ldots \ldots \ldots \ldots \ldots \ldots \ldots \\
& V_{M}=\left(\rho_{G} J_{G}+\rho_{L} J_{L}\right) / \rho_{M} \\
& V_{G j}^{*}=V_{G}-J_{M} \ldots \ldots \ldots \ldots \ldots \ldots
\end{aligned}
$$

また，混合体の体積流束 $J_{M}$ は次式によって表される。

$$
J_{M}=J_{G}+J_{L}
$$

なお，気相の平均速度 $V_{G}$ は，分布パラメータを $C_{G 0}$, 気体体積 率加重断面平均ドリフト速度を $V_{G j}$ とすれば，次式によって表さ れる。

$$
V_{G}=C_{G 0} J_{M}+V_{G j}
$$

したがって，式 (9) を式 (7) に代入すれば, 気相の平均ドリフト 速度 $V_{G j}^{*}$ は，次式によって表される。

$$
V_{G j}^{*}=\left(C_{G 0}-1\right) J_{M}+V_{G j}
$$

さて, 密度は状態方程式によって与えられる。それゆえ，壁 面せん断応力 $\tau_{W}$ および気相の平均ドリフト速度 $V_{G j}^{*}$ を構成方程 式とすれば，基礎方程式（1）ないし（3）は， $f_{G}, V_{M}$ および $P$ を末 知数とする連立非線形方程式とみなされる。なお， $\tau_{W}$ ならびに $V_{G j}^{*}$ に関わる $C_{G 0}$ および $V_{G j}$ に対して相関式として与える必要が ある。

\section{$2 \cdot 2$ 構成方程式に対する相関式}

$2 \cdot 2 \cdot 1$ 平均ドリフト速度に関する相関式 大口径管におけ る分布パラメータおよび気体体積率加重断面平均ドリフト速度の 相関式が Kataoka ら ${ }^{14)}$ および Hibiki ら ${ }^{15,16)}$ によって提示され ており, Ishii-Hibikiによる著書 ${ }^{17)}$ にまとめられている。大口径 管の判定は，無次元管径 $N_{D}$ を用いて，次式によって行われる。

$$
N_{D} \geq 30 \text {; 大口径管 }
$$

$N_{D}<30 ;$ 小中口径管

なお，無次元管径 $N_{D}$ は次式によって表される。

$$
N_{D}=D / l_{C}
$$

ここに, $l_{C}$ は, 物性值によって一義的に決まる特性長さであり， 次式によって表される ${ }^{21)}$

$$
l_{C}=\sqrt{\sigma /(g \Delta \rho)}
$$

$$
\Delta \rho=\rho_{L}-\rho_{G}
$$

さて, 気体体積率加重断面平均ドリフト速度 $V_{G j}$ は, 無次元化 した次式によって表示される。

$$
V_{G j}^{+}=V_{G j} / V_{K U}
$$

ここに， $V_{K U}$ は特性速度であり，次式によって表される ${ }^{21) 。 ~}$

$V_{K U}=\left(\frac{\sigma g \Delta \rho}{\rho_{L}{ }^{2}}\right)^{1 / 4}$

式 (16) は, 特性長さ $l_{C}$ を用いれば, 次式のように変形すること ができる。

$$
V_{K U}=\sqrt{g l_{C} \Delta \rho / \rho_{L}}
$$

ここで, 本研究で採用した分布パラメータ $C_{G 0}$ および無次元化 した気体体積率加重断面平均ドリフト速度 $V_{G j}^{+}$を流動様式ごとに 示す。ただし，流動様式の区分は大局的に行い ${ }^{22)}$ ，気泡流，間 欠流 (球冠状気泡流・スラグ流・団塊波流を含む) および環状流 の3つとした。

気泡流に対して ${ }^{2,15,17,21)}$.

$C_{G 0, B}=\left(1.2-0.2 \sqrt{\rho_{G} / \rho_{L}}\right)\left\{1-\exp \left(-18 f_{G}\right)\right\}$

$V_{G j, B}^{+}=1.41\left(1-f_{G}\right)^{1.75}$

間久流に対して ${ }^{2,14,16,17,21)}$ :

$C_{G 0, I}=1.2-0.2 \sqrt{\rho_{G} / \rho_{L}}$

$N_{\mu L} \leq 2.25 \times 10^{-3}$ の場合 ;

$V_{G j, I}^{+}=0.0019 N_{D}^{0.809}\left(\rho_{G} / \rho_{L}\right)^{-0.157} N_{\mu L}^{-0.562}, N_{D} \leq 30 \cdots$

$V_{G j, I}^{+}=0.030\left(\rho_{G} / \rho_{L}\right)^{-0.157} N_{\mu L}^{-0.562}, N_{D} \geq 30$

$N_{\mu L}>2.25 \times 10^{-3}$ の場合 ;

$V_{G j, I}^{+}=0.92\left(\rho_{G} / \rho_{L}\right)^{-0.157}$

ここに, $N_{\mu L}$ は液相の無次元粘度であり, 次式によって表される。

$$
N_{\mu L}=\frac{\mu_{L}}{\left\{\rho_{L} \sigma \sqrt{\sigma /(g \Delta \rho)}\right\}^{1 / 2}}
$$

なお，式 (22) は特性長さ $l_{C}$ を用いれば，次式のように簡潔に表 され， $l_{C}$ を代表長さとする Ohnesorge 数と一致する。

$N_{\mu L}=\frac{\mu_{L}}{\sqrt{\rho_{L} \sigma l_{C}}}$

環状流に対して ${ }^{2,16,17,21) ：}$

$C_{G 0, A}=1+C_{A}$

$V_{G j, A}^{+}=\frac{C_{A}}{V_{K U}} \sqrt{\frac{g D \Delta \rho\left(1-f_{G}\right)}{0.015 \rho_{L}}}$

ここに， $C_{A}$ は次式によって表される。

$C_{A}=\frac{1-f_{G}}{f_{G}+\sqrt{\left\{1+75\left(1-f_{G}\right)\right\} \rho_{G} /\left(\sqrt{f_{G}} \rho_{L}\right)}}$

なお，式 (24) は無次元管径 $N_{D}$ を用いれば，次式のように簡潔に 


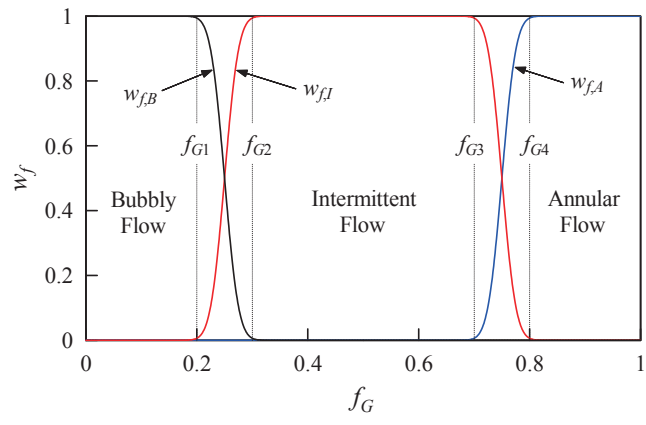

Fig.1 Weighted factors of interpolation for flow regime transitions.

表される。

$$
V_{G j, A}^{+}=C_{A} \sqrt{\frac{\left(1-f_{G}\right) N_{D}}{0.015}}
$$

ところで，流動様式の変化は徐々に起こるため，流動様式間に 遷移領域を設け，その領域において遷移に関わる相間式に重み係 数を掛けて補間したが，Fig. 1 に示すように，遷移領域は簡便さ を考慮し気体体積率のみによって決定されるものとした。各流動 様式に対する重夕係数をそれぞれ $w_{f, B}, w_{f, I}$ および $w_{f, A}$ とすれば ( 付録 $\mathrm{A}$ 参照)，分布パラメータ $C_{G 0}$ および無次元化した気体体 積率加重断面平均ドリフト速度 $V_{G j}^{+}$は次式によって与えられる。

$$
\begin{aligned}
& C_{G 0}=w_{f, B} \cdot C_{G 0, B}+w_{f, I} \cdot C_{G 0, I}+w_{f, A} \cdot C_{G 0, A} \\
& V_{G j}^{+}=w_{f, B} \cdot V_{G j, B}^{+}+w_{f, I} \cdot V_{G j, I}^{+}+w_{f, A} \cdot V_{G j, A}^{+} \ldots
\end{aligned}
$$

$2 \cdot 2 \cdot 2$ 壁面せん断応力に関する相関式＼cjkstart壁面せん断応 力 $\tau_{W}$ は, Lockhart-Martinelli 法 ( 以後 L-M 法と略記 ) に対する Chisholm-Laird の相関式によって与えた ${ }^{23)}$ 。

$$
\frac{4 \tau_{W}}{D}=\frac{\Delta P_{L 0}}{\Delta z}+\frac{\Delta P_{G 0}}{\Delta z}+A \sqrt{\frac{\Delta P_{L 0}}{\Delta z} \cdot \frac{\Delta P_{G 0}}{\Delta z}}
$$

$A=83 N_{D}{ }^{-0.37}$

ここに,

$$
\frac{\Delta P_{k 0}}{\Delta z}=\lambda_{k} \frac{1}{D} \frac{\rho_{k} J_{k}^{2}}{2},(k=G, L)
$$

であり，管摩擦係数 $\lambda$ は，次式で示される揚鉱管の内壁粗さ $\varepsilon$ を 考慮したコールブルック (Colebrook) の式で与えられる。

$$
\begin{aligned}
& \frac{1}{\sqrt{\lambda_{k}}}=-2 \log \left(\frac{\varepsilon / D}{3.71}+\frac{2.51}{R e_{k} \sqrt{\lambda_{k}}}\right),(k=G, L) \\
& R e_{k}=\frac{\rho_{k} D J_{k}}{\mu_{k}},(k=G, L)
\end{aligned}
$$

なお，式 (27b) は付録 B に示したとおり，本研究において再評価 したものである。

\section{$2 \cdot 3$ 境界に関わる圧力損失}

小規模なエアリフトポンプほど，出入口損失ならびに助走損失 が顕在化すると考えられる。それらの損失は，Fig. 2 に示すよう に，それぞれの境界において考慮するものとすれば，次式のよう に表される ${ }^{18)}$ 。

$$
\begin{aligned}
& \Delta P_{i n}=P_{i n}-P_{i n}^{\prime}=\left(\zeta_{i n}+\xi_{i n}\right) \frac{\rho_{L} J_{L}^{2}}{2} \ldots \ldots \ldots \ldots \ldots \ldots \ldots \ldots \ldots \ldots \ldots \ldots \ldots \ldots \ldots \\
& \Delta P_{a i}=P_{a i}-P_{a i}^{\prime \prime}=\zeta_{a i} \frac{\rho_{L} J_{L}^{2}}{2}\left\{\frac{\rho_{M}}{\left(1-f_{G, a i}\right)^{2}}-\rho_{L}\right\}+\xi_{a i} \frac{\rho_{M} J_{M}^{2}}{2}
\end{aligned}
$$

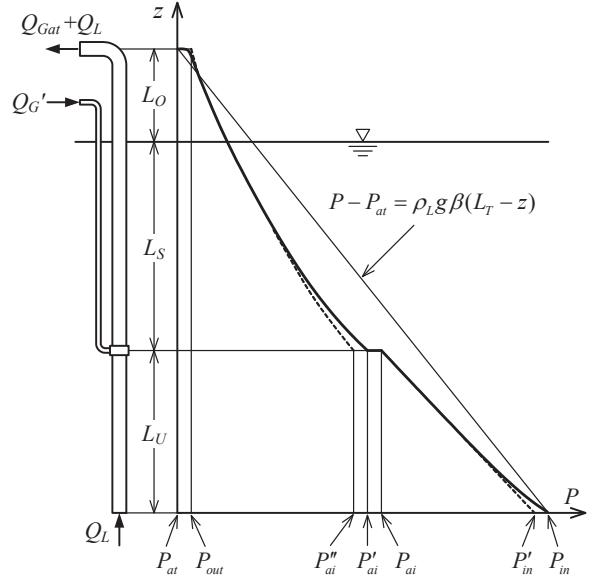

Fig.2 Schematic diagram of static pressure distribution in an airlift pipe.

$$
\Delta P_{\text {out }}=P_{\text {out }}-P_{\text {at }}=\zeta_{\text {out }} \frac{\rho_{M} J_{M}^{2}}{2}
$$

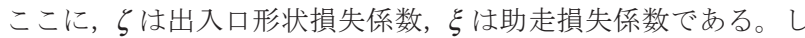
たがって, エアリフト管吸込口における圧力 $P_{i n}^{\prime}$ は次式によって 与えられる。

$$
P_{i n}^{\prime}=\rho_{L} g\left(L_{S}+L_{U}\right)-\Delta P_{i n}+P_{a t}
$$

\section{$2 \cdot 4$ 数值解法の概要}

数值解法は, 既報 ${ }^{5-7)}$ と同様であるが, 概要を記せば次のとお りである。基礎方程式を有限体積法によって離散化し，完全陰解 法および上流法を適用した。その際，スタガード格子を用い，運 動量保存式の解法には SIMPLER 法 ${ }^{4)}$ を採用した。このようにし て導出された離散方程式の係数行列は三重対角行列となってお り,TDMA (三重対角行列アルゴリズム) を用いた逐次解法によっ て効率よく計算することができる。ただし, 離散方程式は非線形 であるため緩和係数を用いて計算を遂行した。なお，定常解は時 間発展的に求められる。

\section{3. 数値計算結果ならびに考察}

エアリフト管長が短いエアリフトポンプにおいては助走域の距 離が相対的に長くなると考えられる。その場合を考慮し，助走域 における分布パラメータ $C_{G 0}$ および無次元気体体積率加重断面 平均ドリフト速度 $V_{G j}^{+}$に対する相関式 ${ }^{16,17)}$ ( 付録 $\mathrm{C}$ 参照) につ いても検討することとした。また，既報 6, 7, 11-13) において用い たドリフト速度に関する相関式 ( 付録 $\mathrm{D}$ 参照) についても比較検 討することとした。一方，壁面せん断応力 $\tau_{W}$ に対する相関式と して赤川 ${ }^{24)}$ ならびに勝原 ${ }^{25)}$ による式 (付録 $\mathrm{E}$ 参照) も用いられ

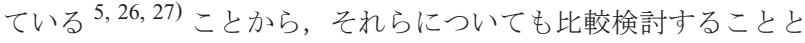
した。これら相関式の組み合わせを Table 1 に示したが, それぞ れの意味するところは次のとおりである。

Corre.1 : 2・2 節において示した相関式を表す。

Corre.2 : 助走域に対する相関式を表す。

Corre.3 : 既報 6,7,11-13) において用いた相関式を表す。

Corre.4 : $C_{G 0}$ および $V_{G j}^{+}$の相関式は Corre.1 と同じであるが, $\tau_{W}$ の相関式が赤川ら ${ }^{24)}$ によるものを表す。

また, 数值計算結果と比較の対象とした実験装置の諸元を Table 2 に示した。なお，数值計算における流動様式の遷移領域に関する パラメータ (Fig. 1 参照) および圧力損失係数の基本条件は以下の とおりである。 
Table 2 Experimental conditions reported by other workers.

Table 1 Correlations for constitutive equations of drift-flux model.

\begin{tabular}{c|c|c|c}
\hline \multirow{2}{*}{$\begin{array}{c}\text { Correlation } \\
\text { No. }\end{array}$} & $C_{G 0}$ & $V_{G j}^{+}$ & \multirow{2}{|c}{$\tau_{W}$} \\
\cline { 2 - 3 } Corr.1 & Eqs.(18),(20),(23) & Eqs.(19),(21),(24) & \multirow{2}{*}{ Eq.(27) } \\
\hline Corr.2 & Eqs.(C-1),(C-6),(23) & Eqs.(C-9),(24) & \\
\hline Corr.3 & Eq.(D-1) & Eqs.(D-2),(D-3) & \\
\hline Corr.4 & Eqs.(18),(20),(23) & Eqs.(19),(21),(24) & \multirow{2}{*}{ Eq.(E-1) } \\
\hline
\end{tabular}

\begin{tabular}{|c|c|c|c|c|c|c|c|}
\hline \multirow{2}{*}{$\begin{array}{l}\text { Data } \\
\text { No. }\end{array}$} & \multirow{2}{*}{ Worker } & \multicolumn{6}{|c|}{ Dimensions of Airlift Pipe } \\
\hline & & $D[\mathrm{~m}]$ & $L_{O}[\mathrm{~m}]$ & $L_{S}[\mathrm{~m}]$ & $L_{U}[\mathrm{~m}]$ & $L_{L} / D[-]$ & $\beta[-]$ \\
\hline $\mathrm{Y} 1$ & Yoshinaga et al. ${ }^{18)}$ & 0.040 & 2.02 & 4.72 & 1.12 & 169 & 0.743 \\
\hline U1 & \multirow{2}{*}{ Usami et al. ${ }^{19) 20)}$} & 0.0757 & 3.49 & 8.15 & 0.84 & 154 & 0.720 \\
\hline $\mathrm{U} 2$ & & 0.155 & 5.76 & 26.87 & 4.96 & 211 & 0.847 \\
\hline $\mathrm{S} 1$ & \multirow{4}{*}{ Saito et al. ${ }^{9)}$} & \multirow{4}{*}{0.151} & \multirow{4}{*}{12.6} & 184 & 16 & 1302 & \multirow{4}{*}{0.941} \\
\hline S2 & & & & 130 & 70 & 944 & \\
\hline S3 & & & & 100 & 100 & 746 & \\
\hline $\mathrm{S} 4$ & & & & 71 & 129 & 554 & \\
\hline W1 & \multirow{2}{*}{ Weber et al. ${ }^{8)}$} & \multirow{2}{*}{0.3} & \multirow{2}{*}{8} & 125 & 5 & 443 & 0.942 \\
\hline W2 & & & & 102 & 341 & 367 & 0.982 \\
\hline
\end{tabular}

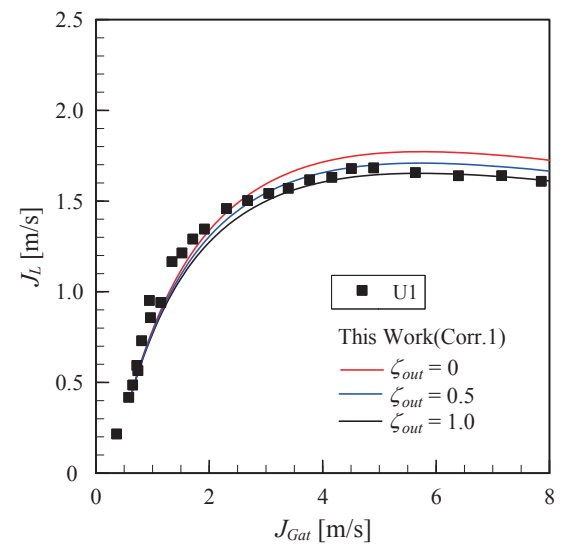

Fig.3 Comparison of calculative results with experimental data of U1.

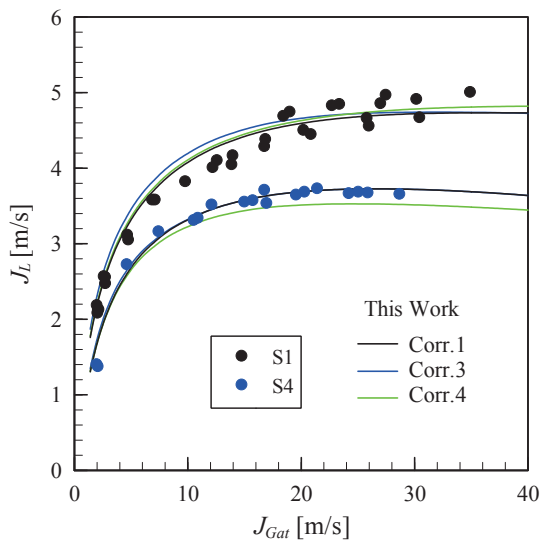

Fig.5 Comparison of calculative result with experimental data of S1 and S4.

・気泡流と間欠流との遷移 $f_{G 1}=0.2, f_{G 2}=0.3$

・間欠流と環状流との遷移 $f_{G 3}=0.7, f_{G 4}=0.8$

- 入口形状損失係数 $\zeta_{\text {in }}+\xi_{\text {in }}=1.56$

. 空気注入損失係数 $\zeta_{a i}=1.0, \quad \xi_{a i}=0.5$

- 出口形状損失係数 $\zeta_{\text {out }}=0$

実験結果と本数值計算結果との比較を大気圧換算送気流束 $J_{G a t}$ と揚水流束 $J_{L}$ との関係として示せば, Figs.3～7 のとおりである。 図中の記号英数字は Table 2 に示した Data No. ならびに実験者と 対応する。大局的には，揚水特性に及ぼすドリフト速度に関する 相関式 (Corr.1 ないし Corr.3) の影響は, さほどみられないと言う ことができる。一方，壁面せん断応力の相関式に関しては，赤川 らによる相関式 (Corr.4) を用いた場合，実験範囲以内では実験值 との一致がみられるが，大口径管において送気流束が大きくなる に従って実験值より小さくなる傾向がみられる。

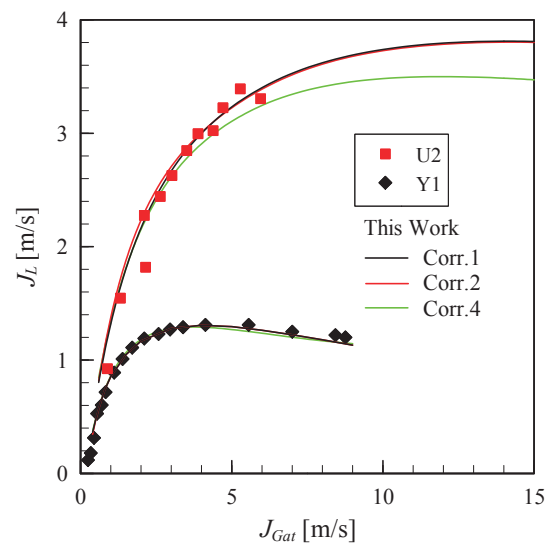

Fig.4 Comparison of calculative result with experimental data of Y1 and U2.

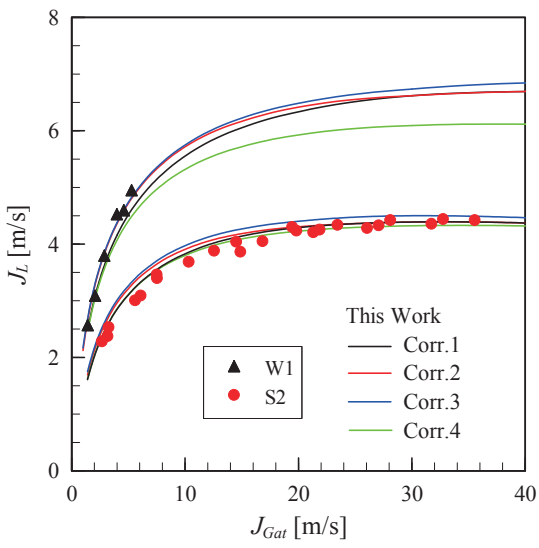

Fig.6 Comparison of calculative result with experimental data of S2 and W1.

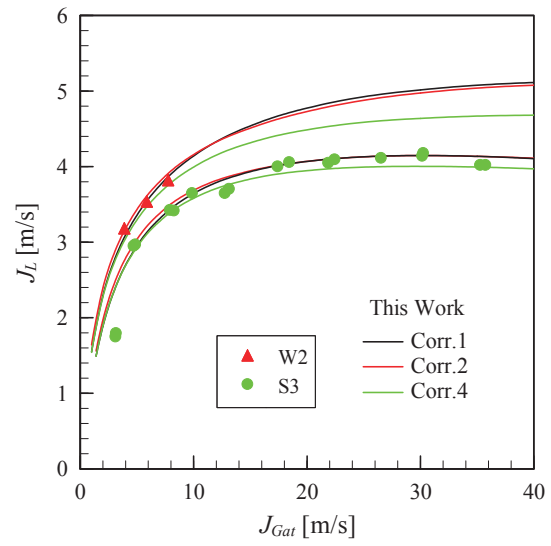

Fig.7 Comparison of calculative result with experimental data of S3 and W2. 


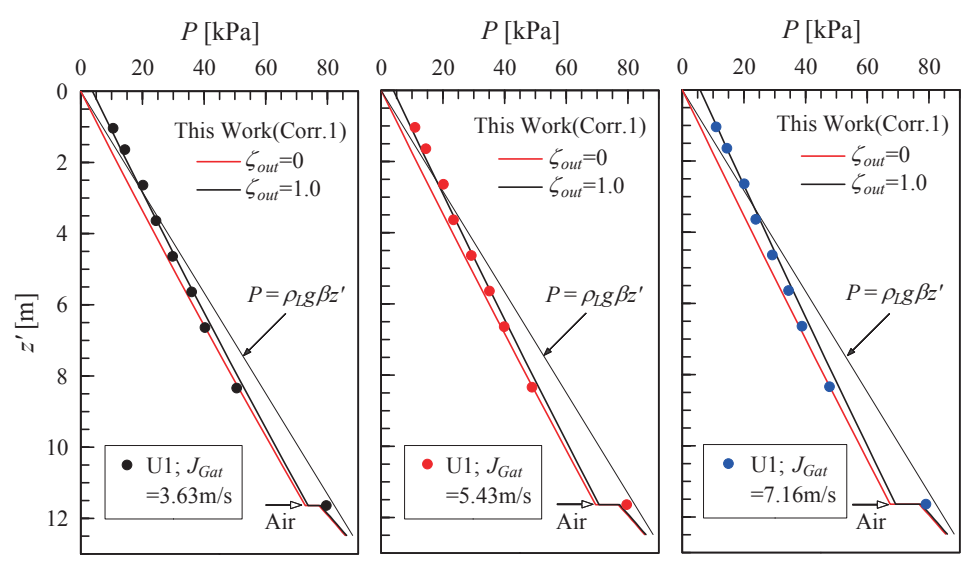

Fig.8 Effect of pressure loss coefficient on static pressure distribution in case of U1.

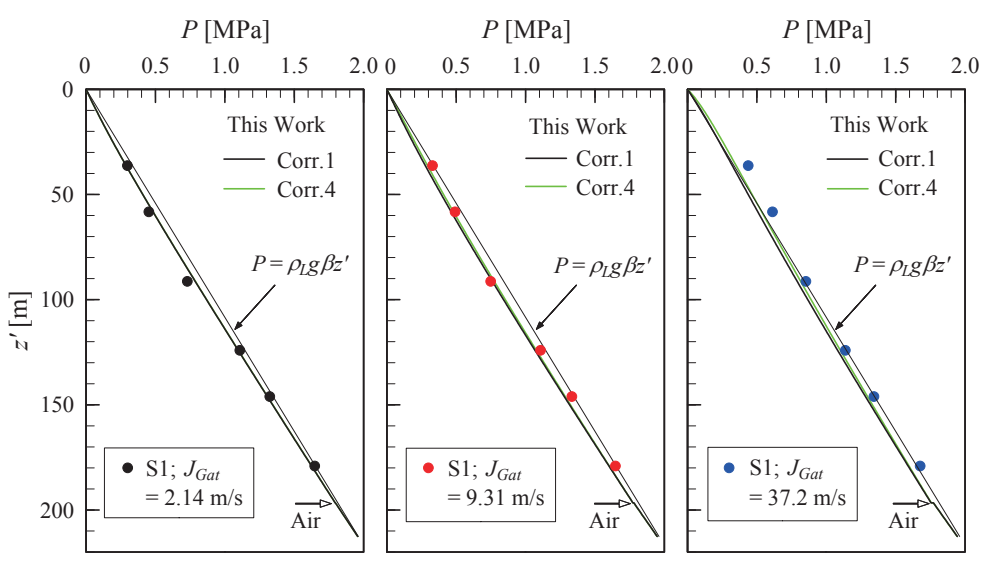

Fig.9 Effect of wall shear stress correlation on static pressure distribution in case of S1.

エアリフトポンプの性能について詳細に議論するためには，気 体体積率および壁面せん断応力の流動方向分布についても把握す る必要がある。次に相関式の違いがそれらに及ぼす影響について 検討する。

\section{$3 \cdot 1$ 境界に関わる圧力損失および圧力分布の検討}

Fig. 3 は, U1 の実験結果 ${ }^{19)}$ と計算結果とを比較したものであ るが, 基本条件として示した出口形状損失係数 out $_{\text {ou }}$ の值 (赤の実 線）では送気流束が大きくなれば，計算結果との相違が大きくな る傾向がみられる。この実験装置のエアリフト管出口にはフレキ シブルホースが付けられて逆U字状に曲げられていることから， Fig. 8 に示される圧力分布の測定結果 ${ }^{28)}$ (ゲージ圧) のとおり, 出口における圧力が大気圧より高くなっている。出口形状損失係 数の影響について検討し，その計算結果が Fig. 3 および Fig. 8 に

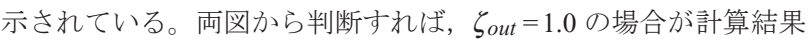
と実験結果とはよく一致していると言える。一方，空気注入に よる損失について注目寸れば，エアリフト管長が短いことから， Fig. 8 に示されているように比較的大きくなっている。なお， $\beta$ については Table 2 に示しているとおりである。

Fig. 9 は, S1 の実験装置における圧力分布の測定結果 ${ }^{29)}$ と計 算結果とを示したものである。送気流束が大きくなれば，壁面せ 几断応力の相関式の影響は多少みられるものの, この場合にはエ アリフト管長が長いことから, 空気注入による圧力損失は相対的 にかなり小さくなっていることが分かる。

\section{$3 \cdot 2$ 損失勾配の検討}

Fig. 10 は, 送気流束に対する各損失勾配の計算結果と静圧勾
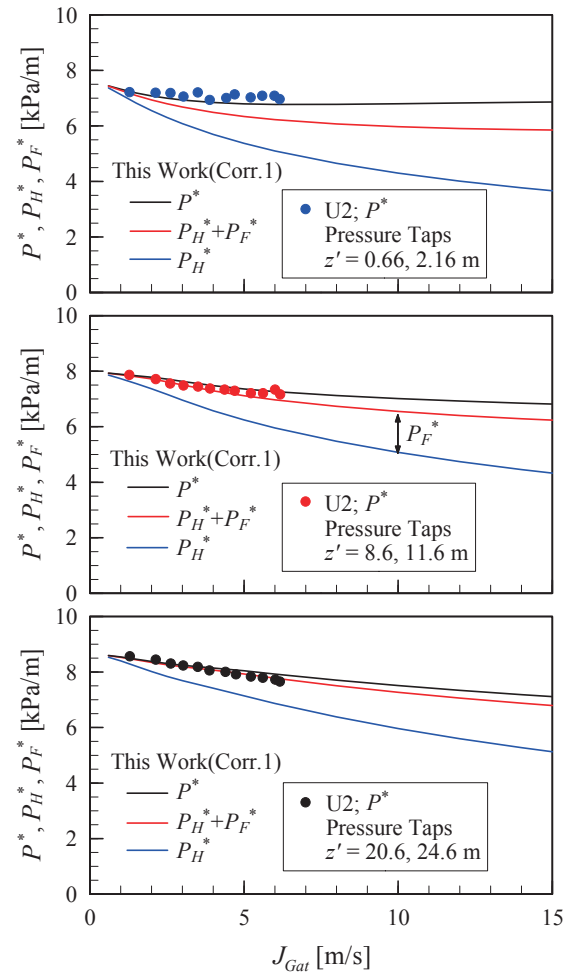

Fig.10 Effect of volumetric flux of air supply on pressure lose gradients in case of $\mathrm{U} 2$. 
配 $P^{*}$ の実験結果 ${ }^{28)}$ とを図示したものである。U2 の実験は海洋 で行われたものであり，差圧は空気注入付近，中央および出口付 近の 3 力所で測定されている。実験結果と計算結果とは全体的に はよく一致していると言える。また, 送気流束が大きくなるに従っ て, 位置損失勾配 $P_{H}{ }^{*}$ はどの位置おいても減少するが, 摩擦損 失勾配 $P_{F}{ }^{*}$ は増加する。黒の実線と赤の実線との差によって表さ れる加速損失勾配 $P_{A}{ }^{*}\left(=P^{*}-P_{H}{ }^{*}-P_{F}{ }^{*}\right)$ は，送気流束と共に大き くなっており,出口付近の位置において顕著となることが分かる。

\section{$3 \cdot 3$ 壁面せん断応力の検討}

L-M 法における係数として式 (27b) を用いた Corr.1 の計算結果 は実験結果とよく一致しているが，赤川らによる式 (E-1) を用い た Corr.4 の計算結果は大口径管において送気流束が大きくなる に従って実験結果より小さくなる傾向がみられる。次にこのこと について考察する。

Fig. 11 は，摩擦損失勾配 $P_{F}{ }^{*}$ の分布の計算結果を，相関式の 違いによって揚水特性が同じな場合 (S2) と相違する場合 (W1) に ついての一例を示したものである (Fig. 6 を参照)。なお, S2 と W1 とは空気注入口の深さがほぼ同じで管径がほぼ倍違ってい る。同図に示されるとおり，何れの場合にも摩擦損失勾配の分布 は，Corr.1 の場合には比較的滑らかに出口に向かって増加してお り, Corr.4の場合には出口付近において比較的急激に増加してい る。また, Corr.1 と Corr.4 とは途中で交差している。摩擦損失勾 配分布の傾向が異なっていても，3・5 節において述べるとおり， 揚水特性に影響しない場合もある。ただし，大口径・大深度エア リフトポンプにおいては，壁面せん断応力は出口付近で急激に大

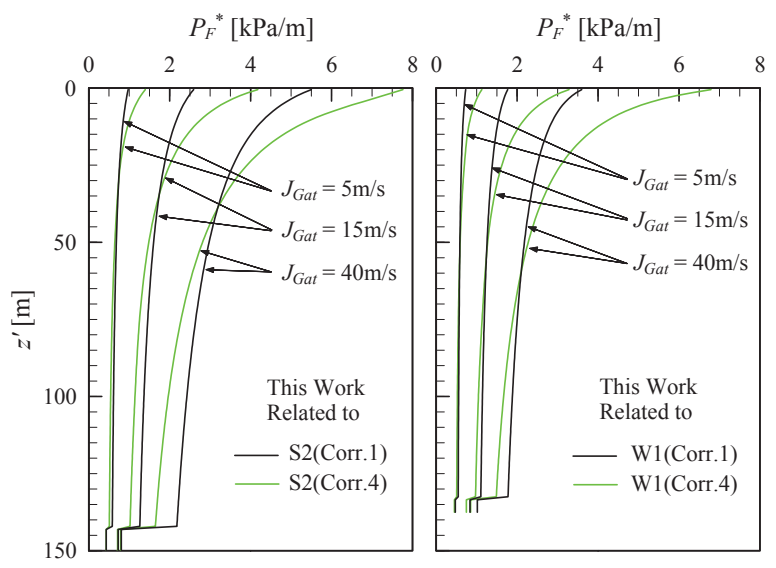

Fig.11 Effect of wall shear stress correlation on frictional loss gradient in cases of S2 and W1.

きくなる傾向はより顕著になることから，赤川らによる相関式の 適用には注意を要すると考えられる。

\section{$3 \cdot 4$ ドリフト速度の検討}

Fig. 12 はS2 に対する計算結果を, Fig. 13 はW1 に対する計 算結果を図示したものである。Corr.2 は本来助走域部分のみに適 用するべきであるが，相関式の違いによる相違点を明らかにする ため, 助走域部分に限定せず適用した。両図の比較は Fig. 11 で 触れたように管径の影響について議論することに対応する。なお， $f_{G}$ の図より流動様式は両図共に気泡流，間欠流ならびにそれら

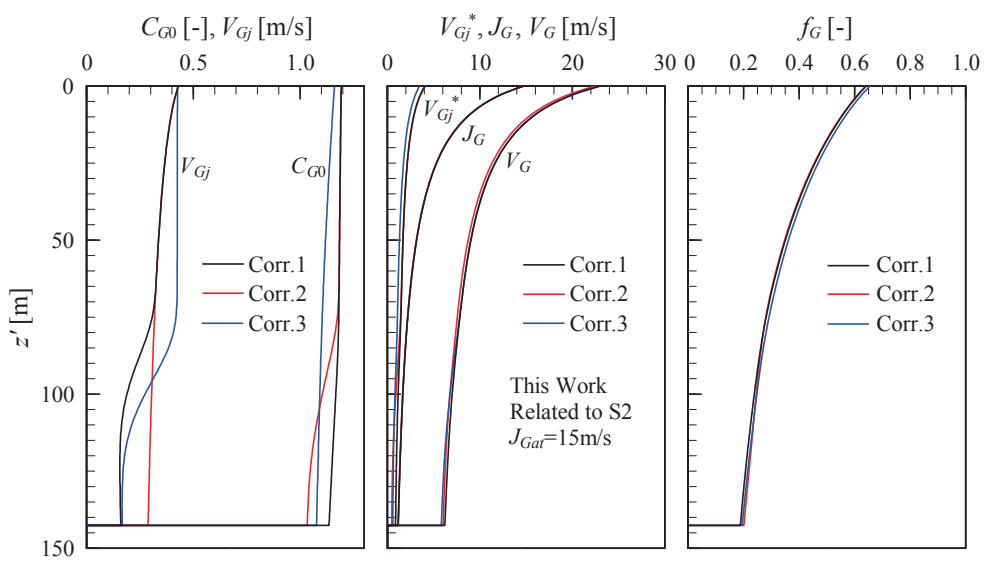

Fig.12 Effect of drift-flux correlations on velocities and volume fraction of gas phase in case of S2.
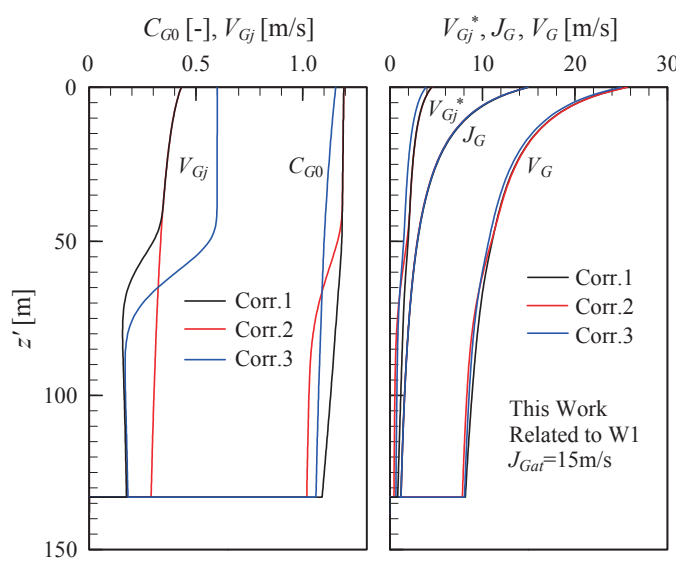

$f_{G}[-]$

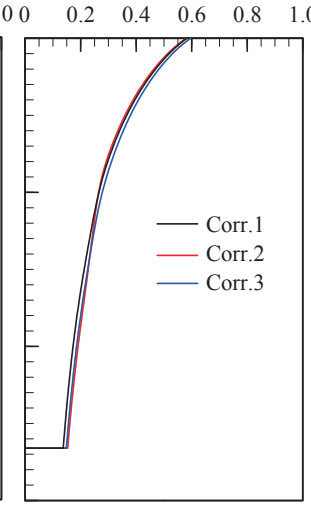

Fig.13 Effect of drift-flux correlations on velocities and volume fraction of gas phase in case of W1. 
の遷移である。

$3 \cdot 4 \cdot 1$ 分布パラメータ 何れの相関式も管径に関わらな いことから，Fig. 12 と Fig. 13 共に同様な傾向となっている。す なわち，Corr.1の場合には気泡流では気体体積率 $f_{G}$ の影響が多 少みられ，空気注入口付近において $C_{G 0} \simeq 1.1$ となっているもの の, 間久流ではほぼ一定で $C_{G 0} \simeq 1.2$ となっている。Corr.2の場 合には気泡流では $C_{G 0} \simeq 1.0$, 間欠流では $C_{G 0} \simeq 1.2$, 遷移領域で はそれらの加重平均となっている。Corr.3の場合には空気注入口 付近において $C_{G 0} \simeq 1.05$ であり, 出口に向かって徐々に増加し $C_{G 0} \rightarrow 1.2$ となる傾向となっている。

$3 \cdot 4 \cdot 2$ 気体体積率加重断面平均ドリフト速度 大口径管で は, Corr.1の相関式は管径に関わらないことから, 遷移領域の位 置は異なるものの, Fig. 12 と Fig. 13 共に同様の傾向となっている。 Corr.2の相関式は, 無次元気体体積流束 $J_{G}^{+}\left(=J_{G} / V_{K U}\right)$ が 5 程度 以上になれば, Corr.1 の間久流の相関式と等価となる。また, 特 性速度 $V_{K U}$ は $0.16 \mathrm{~m} / \mathrm{s}$ 程度であるから, Corr.2 の場合には気泡流 においても同一の相関式が適用されるため，流動様式に関わらず 滑らかな曲線となっている。Corr.3の場合には気泡流では管径に 依存しないため両図共に同程度であるが，間欠流では管径の影響 が大きくなっている (Fig. 12 においては $V_{G j} \simeq 0.43 \mathrm{~m} / \mathrm{s}$, Fig. 13 に おいては $\left.V_{G j} \simeq 0.60 \mathrm{~m} / \mathrm{s}\right)$ 。遷移領域では両流動様式における值を 用いた加重平均によって表されることから, Corr.3 の場合には遷 移領域で大きな変化を呈している。

$3 \cdot 4 \cdot 3$ 気体平均速度および気体体積率気体体積率 $f_{G}$ は, 次式によって表される。

$$
f_{G}=\frac{J_{G}}{V_{G}}=\frac{J_{G}}{C_{G 0}\left(J_{G}+J_{L}\right)+V_{G j}}
$$

ここに, 気体体積流束 $J_{G}$ は状態方程式より次式によって与えら れる。

$$
J_{G}=\frac{P_{a t} J_{G a t}}{P+P_{a t}}
$$

Fig. 9 に示されるように圧力分布は相関式によってほとんど影響 されないことから, Fig. 12 および Fig. 13 における気体体積流束 分布も相関式の影響を受けないことが分かる。前述のように大口 径管において，気泡流と間欠流とで， $C_{G 0}$ の值には Corr.2 の場合 に比較的顕著な違いが見られ, 一方, $V_{G j}$ の值には Corr.3の場合 に顕著な違いが見られた。しかしながら, Fig. 12 および Fig. 13 に示されるように気体平均速度 $V_{G}$ および気体体積率 $f_{G}$ の流動方 向分布に及ぼす相関式の影響は, 多少みられるものの, 揚水特性 に大きく影響するほどではないと言える。

\section{$3 \cdot 5$ エアリフトポンプにおける諸損失の評価}

エアリフトポンプの性能を論じる場合, 空気注入口における管 内圧 $P_{a i}$ が重要な役割を果たす ${ }^{13)}$ 。空気注入口より上流側およ び下流側に着目すれば，それぞれ次式によって表される。

$$
\begin{gathered}
P_{a i}=\rho_{L} g L_{S}-\lambda_{L} \frac{L_{U}}{D} \frac{\rho_{L} J_{L}^{2}}{2}-\Delta P_{i n} \ldots \ldots \ldots \ldots \ldots \ldots \ldots \ldots \ldots \ldots \ldots \ldots \ldots \\
P_{a i}=\int_{L_{L}}^{0}\left\{P_{A}{ }^{*}\left(z^{\prime}\right)+P_{F}^{*}{ }^{*}\left(z^{\prime}\right)+P_{H}{ }^{*}\left(z^{\prime}\right)\right\} \mathrm{d} z^{\prime}+\Delta P_{o u t}+\Delta P_{a i} \ldots \ldots .
\end{gathered}
$$

式 (37b) の加速損失, 摩擦損失および位置損失成分を具体的に示 せば, 次式のとおりである。ただし，エアリフト管は垂直とする。

$$
\Delta P_{A, L L}=\int_{L_{L}}^{0} P_{A}^{*}\left(z^{\prime}\right) \mathrm{d} z^{\prime}=\left[\rho_{M, i} V_{M, i}^{2}+\frac{f_{G, i} \rho_{G, i} \rho_{L}}{f_{L, i} \rho_{M, i}} V_{G j, i}^{*}\right]_{1}^{n_{2}+1}
$$

$$
\begin{gathered}
\Delta P_{F, L L}=\int_{L_{L}}^{0} P_{F}{ }^{*}\left(z^{\prime}\right) \mathrm{d} z^{\prime} \cong \frac{4}{D} \sum_{i=1}^{n_{2}} \tau_{W, i} \Delta z \\
\Delta P_{H, L L}=\int_{L_{L}}^{0} P_{H}{ }^{*}\left(z^{\prime}\right) \mathrm{d} z^{\prime} \cong \rho_{L} g L_{L}-g \sum_{i=1}^{n_{2}} f_{G, i}\left(\rho_{L}-\rho_{G, i}\right) \Delta z
\end{gathered}
$$

ここに, $n_{2}$ は $L_{L}$ 部の格子分割数であり, $\Delta z=L_{L} / n_{2}$ である。式 (37a) と (37b) とを等值し， $\rho_{L} g$ で割り整理すれば次式のようになる。

$$
H_{W, L L}=L_{O}+H_{F, L L}+H_{F, L U}+H_{A, L L}+H_{\Delta}
$$

ここに,

$$
\begin{aligned}
& H_{W, L L}=\frac{1}{\rho_{L}} \sum_{i=1}^{n_{2}} f_{G, i}\left(\rho_{L}-\rho_{G, i}\right) \Delta z \\
& H_{F, L L}=\frac{\Delta P_{F, L L}}{\rho_{L} g}, H_{F, L U}=\lambda_{L} \frac{L_{U}}{D} \frac{J_{L}^{2}}{2 g} \\
& H_{A, L L}=\frac{\Delta P_{A, L L}}{\rho_{L} g}, H_{\Delta}=\frac{\Delta P_{i n}+\Delta P_{a i}+\Delta P_{o u t}}{\rho_{L} g}
\end{aligned}
$$

である。式 (41) の左辺, すなわち式 (42a) は注入された空気が単 位重量当たりに為す仕事 (単位: $\mathrm{J} / \mathrm{N}=\mathrm{m}$ ) である。また, 式 (41) の右辺は諸損失をへッドで表したものであり, 第 1 項は実揚程, 全体は全揚程と見なすことができる。それゆえ, 式 (41) はエア リフトポンプの性能評価式と言うことができる。Table 3 は, 最 大揚水付近における諸損失の計算結果の一例を示したものであ る。ただし, 式 (41) の右辺における諸損失を $H_{W, L L}$ との比とし て示した。同表に示されるように, $H_{W, L L}$ には相関式による相 違はさほど見られないが, $R F L L$ すなわち $L_{L}$ 部の摩擦損失には, Fig. 11 のように相違する場合とそうでない場合があることが分 かる。 $R_{F L L}$ の值は, $\mathrm{U} 2, \mathrm{~S} 4, \mathrm{~W} 1$ および $\mathrm{W} 2$ では Corr.4 (赤川ら による相関式) の方が大きくなっており, $R_{L O}\left(L_{O}\right.$ 部の位置損失) を除いた他の諸損失より相対的に大きいため, 揚水特性の計算結 果が実験結果より小さくなったものと考えられる。

\section{$3 \cdot 6$ 数値計算結果の総括}

本研究で取り上げた実験結果とCorr.1 を用いた計算結果とを 送気流量と揚水流量との関係として一括して図示寸れば, Fig. 14 のとおりである。大口径管のみならず小中口径管においても両者 はよく一致している。このように $2 \cdot 2$ 節に示した平均ドリフト 速度に関わる相関式は, 物理的背景も明らかであり実験的にも吟 味されていることから, 大口径管のエアリフトポンプに対して推 奨することができると言える。

\section{4.おわりに}

先に著者らが開発したエアリフトシミュレーターにドリフトフ ラックスモデルの構成方程式に関わる近年の研究結果を取り込む と共に, 以前の相関式と対比しながら, それらが揚水特性に及ぼ 寸影響等について検討したところ, 次のようなことが結論として 得られた。

1) 平均ドリフト速度に関わる $C_{G 0}$ および $V_{G j}$ の值は相関式によっ て異なるものの, 気体平均速度および気体体積率分布にはさほ ど影響を及ぼさず，その結果揚水量にも殆じ影響を及ぼさない ことが分かった。

2) 赤川らによる壁面せん断応力の相関式は, 大口径管において送 気流束が大きい場合, 実験結果より小さくなる傾向がみられ たが，その原因を摩擦圧力勾配分布により説明することができ た。

3)エアリフトポンプの性能評価式を提示すると共に, 評価式の各 
Table 3 Ratio of pressure losses to work of injected air in airlift pipes.

\begin{tabular}{|c|c|c|c|c|c|c|c|c|c|}
\hline $\begin{array}{l}\text { Data } \\
\text { No. }\end{array}$ & $\begin{array}{c}\text { Corr. } \\
\text { No. }\end{array}$ & $\begin{array}{c}J_{\text {Gat }} \\
{[\mathrm{m} / \mathrm{s}]}\end{array}$ & $\begin{array}{c}J_{L} \\
{[\mathrm{~m} / \mathrm{s}]}\end{array}$ & $\begin{array}{c}H_{W, L L} \\
{[\mathrm{~m}]}\end{array}$ & $\begin{array}{l}R_{L O} \\
{[\%]}\end{array}$ & $\begin{array}{l}R_{F L L} \\
{[\%]} \\
\end{array}$ & $\begin{array}{l}R_{F L U} \\
{[\%]} \\
\end{array}$ & $\begin{array}{c}R_{A} \\
{[\%]}\end{array}$ & $\begin{array}{c}R_{\Delta} \\
{[\%]} \\
\end{array}$ \\
\hline \multirow{2}{*}{ Y1 } & Corr. 1 & \multirow{2}{*}{3} & 1.28 & 3.56 & 56.7 & 31.2 & 1.4 & 1.4 & 9.3 \\
\hline & Corr. 4 & & 1.28 & 3.56 & 56.7 & 31.3 & 1.4 & 1.4 & 9.2 \\
\hline \multirow{2}{*}{ U1 } & Corr. 1 & \multirow{2}{*}{6} & 1.72 & 6.74 & 51.8 & 23.3 & 0.4 & 2.1 & 22.3 \\
\hline & Corr. 4 & & 1.66 & 6.80 & 51.3 & 24.9 & 0.4 & 2.0 & 21.4 \\
\hline \multirow{2}{*}{ U2 } & Corr. 1 & \multirow{2}{*}{10} & 3.73 & 14.8 & 39.0 & 30.7 & 2.0 & 8.5 & 19.9 \\
\hline & Corr.4 & & 3.48 & 15.0 & 38.3 & 33.9 & 1.7 & 7.4 & 18.7 \\
\hline \multirow{2}{*}{ S1 } & Corr.1 & \multirow{2}{*}{30} & 4.72 & 72.2 & 17.5 & 68.4 & 2.1 & 6.9 & 5.1 \\
\hline & Corr. 4 & & 4.77 & 70.0 & 18.0 & 67.0 & 2.2 & 7.1 & 5.8 \\
\hline \multirow{2}{*}{ S2 } & Corr. 1 & \multirow{2}{*}{30} & 4.39 & 62.2 & 20.3 & 57.8 & 9.3 & 6.8 & 5.8 \\
\hline & Corr. 4 & & 4.32 & 61.2 & 20.6 & 57.4 & 9.2 & 6.6 & 6.2 \\
\hline \multirow{2}{*}{ S3 } & Corr.1 & \multirow{2}{*}{30} & 4.13 & 55.6 & 22.6 & 51.0 & 13.3 & 6.4 & 6.6 \\
\hline & Corr.4 & & 3.98 & 55.4 & 22.7 & 52.1 & 12.5 & 6.0 & 6.6 \\
\hline \multirow{2}{*}{ S4 } & Corr.1 & \multirow{2}{*}{30} & 3.71 & 47.2 & 26.7 & 43.2 & 16.7 & 5.6 & 7.8 \\
\hline & Corr.4 & & 3.49 & 47.4 & 26.6 & 46.1 & 14.9 & 5.0 & 7.5 \\
\hline \multirow{2}{*}{ W1 } & Corr.1 & \multirow{2}{*}{30} & 6.64 & 48.7 & 16.4 & 52.6 & 1.0 & 16.4 & 13.5 \\
\hline & Corr. 4 & & 6.09 & 49.6 & 16.1 & 57.1 & 0.9 & 13.8 & 12.1 \\
\hline \multirow{2}{*}{ W2 } & Corr.1 & \multirow{2}{*}{30} & 5.01 & 53.2 & 15.0 & 28.9 & 37.9 & 9.2 & 9.0 \\
\hline & Corr.4 & & 4.64 & 53.3 & 15.0 & 36.2 & 32.5 & 8.0 & 8.2 \\
\hline
\end{tabular}

$R_{L O}=\frac{L_{O}}{H_{W, L L}}, \quad R_{F L L}=\frac{H_{F, L L}}{H_{W, L L}}, \quad R_{F L U}=\frac{H_{F, L U}}{H_{W, L L}}, \quad R_{A}=\frac{H_{A, L L}}{H_{W, L L}}, R_{\Delta}=\frac{H_{\Delta}}{H_{W, L L}}$

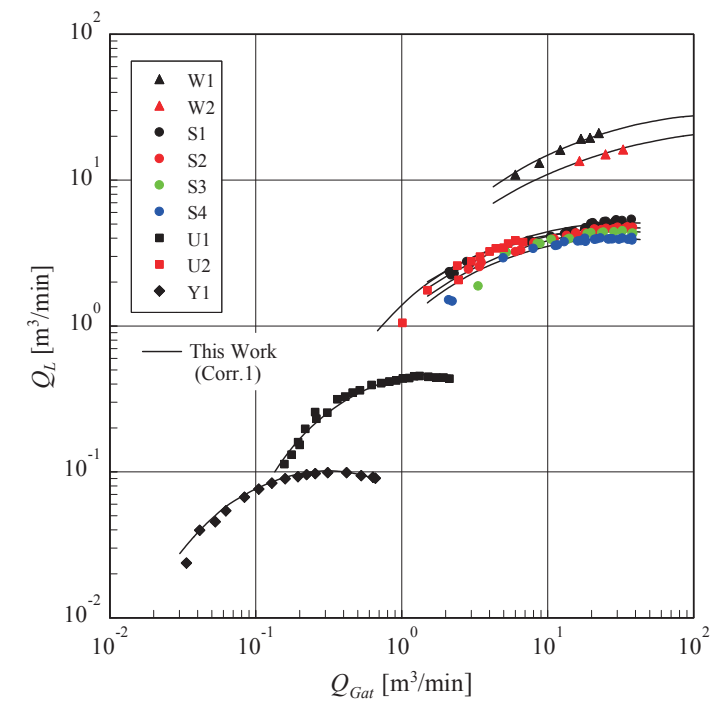

Fig.14 Comparison of calculative results of this work with experimental results of other workers.
項を数値解より計算し, それらの比率が揚水特性に影響するこ

とを明らかにした。

4) $2 \cdot 2$ 節に示した相関式は，大口径管のみならず小中口径管の エアリフトポンプに対しても適用できることを確認した。

現在，深海底に賦存するレアアース堆積物の揚泥技術の開発が 望まれているが，本研究で検討した構成方程式に対して泥水に関 わるパラメータを取り組めば，エアリフトポンプによる揚泥法と して確立することができると考える。

\section{付 録}

付録A 補間の重み係数 $w_{f}$ は正規分布を用いれば, 次式によっ て与えられる ${ }^{6)}$ 。

$$
w_{f}\left(f_{G} ; \mu_{i j}, \sigma_{i j}\right)=\frac{1}{\sqrt{2 \pi} \sigma_{i j}} \int_{-\infty}^{f_{G}} \exp \left\{-\frac{\left(x-\mu_{i j}\right)^{2}}{2 \sigma_{i j}^{2}}\right\} \mathrm{d} x
$$

$$
\text { ここに, }
$$

$$
\mu_{i j}=\left(f_{G i}+f_{G j}\right) / 2
$$

$\sigma_{i j}=\left(f_{G j}-f_{G i}\right) / 5$

である。したがって，各流動様式に対する重み係数はそれぞれ次 式のように表される。

$$
\begin{aligned}
& w_{f, B}=1-w_{f}\left(f_{G} ; \mu_{12}, \sigma_{12}\right) \\
& w_{f, I}=w_{f}\left(f_{G} ; \mu_{12}, \sigma_{12}\right) \cdot\left\{1-w_{f}\left(f_{G} ; \mu_{34}, \sigma_{34}\right)\right\} \\
& w_{f, A}=w_{f}\left(f_{G} ; \mu_{34}, \sigma_{34}\right)
\end{aligned}
$$

付録B 垂直管内混相流における壁面せん断応力 $\tau_{W}$ の測定は, 圧力変換器等で測定された静圧勾配 $P^{*}$ と締め切り法等で測定さ れた位置損失勾配 $P_{H}{ }^{*}$ とによって, 次式によって間接的に行わ れる。ただし, 加速損失勾配 $P_{A}{ }^{*}$ は一般に無視される。

$$
\frac{4 \tau_{W}}{D}=P_{F}{ }^{*}=P^{*}-P_{H}{ }^{*}
$$

垂直管内気液二相流においては流動様式が様々であり，間欠的な 流動を呈する場合には, 締め切り法によって精度よく $P_{H}{ }^{*}$ を求
めるためにはある程度の測定区間長が必要とされる。また, 十分 発達した状態における $P_{H}{ }^{*}$ の測定は, 助走距離も必要となるた め，大口径管に対しては行われていないが現状である。このよう なことから既報 ${ }^{23)}$ においては, 都田ら ${ }^{30)}$ および宇佐美ら ${ }^{31)}$ の 実験結果を含めて, 3 種の管径 $(18.3,30$ および $46.5 \mathrm{~mm})$ の実験結 果を用いて，L-M 法に対する Chisholm-Laird の相関式，すなわち 式(B-2) おける係数 $A$ を求めた。

$$
\begin{aligned}
& \Phi_{L}{ }^{2}=1+A / X+1 / X^{2} \\
& \Phi_{L}{ }^{2}=\left(\frac{4 \tau_{W}}{D}\right) /\left(\frac{\Delta P_{L 0}}{\Delta z}\right) \\
& X^{2}=\left(\frac{\Delta P_{L 0}}{\Delta z}\right) /\left(\frac{\Delta P_{G 0}}{\Delta z}\right)
\end{aligned}
$$

その際，多少管径の影響が見られたことから，各管径ごとに実験 結果 $\left(X_{i}, \Phi_{L, i} ; i=1,2, \cdots, n_{A}\right)$ より最小二乗法によって, 寸なわち次 式によって係数 $A$ の值を求めた。

$$
A=\sum_{i=1}^{n_{A}}\left(\frac{\Phi_{L, i}^{2}}{X_{i}}-\frac{1}{X_{i}}-\frac{1}{X_{i}^{3}}\right) / \sum_{i=1}^{n_{A}} \frac{1}{X_{i}^{2}}
$$

このようにして得られた係数 $A$ を無次元管径 $N_{D}$ との関係として $\left(N_{D, j}, A_{j} ; j=1,2, \cdots, n_{D}\right)$, さらに最小二乗法によって次式を得た。

$$
A=52 N_{D}{ }^{-0.2}
$$

さて, 式 (B-5) は 3 種の管径から求められている。また係数 $A$ の值を求めた際の実験值の組数 $n_{A}$ は異なっている。一般にデー 夕に重みが付与されていればそのことを考慮すべきであり, 式 (B5) には実験值の組数の違いが反映されていない。そこで, 既報 ${ }^{23)}$ にける実験值に L-M 法に基づいた井伊谷 ${ }^{32)}$ および斯波ら ${ }^{33)}$ の実 験值を加えて, すなわち Fig. A1 に示す実験結果を用いて再評価 することとした。各管径における処理結果を Table A1 に示したが, 重み $w$ は，次式によって表される。

$$
w_{j}=n_{A, j} / \sum_{j=1}^{n_{D}} n_{A, j}
$$




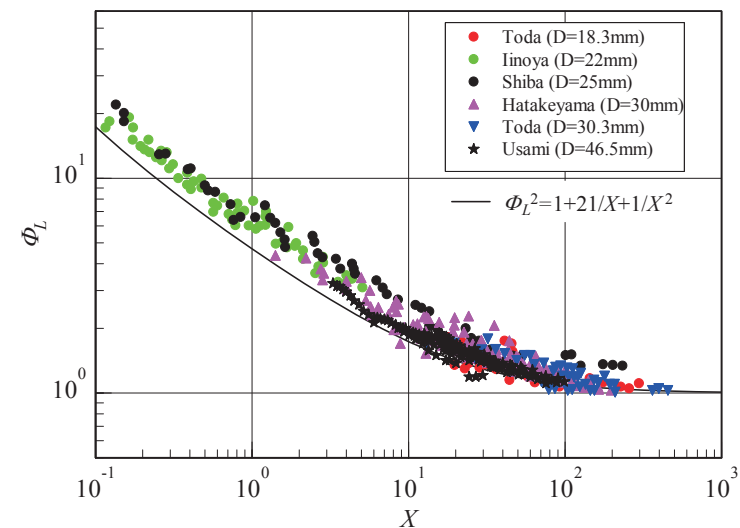

Fig.A1 Represatation of frictional pressure drop with Lockhart-Martinelli method in vertical two-phase flow.

Table A1 に示されるように係数 $A$ は無次元管径 $N_{D}$ に対してばら ついているが，予備的に検討したところ，管径が大きくなれば係 数 $A$ は減少寸る傾向にあった。係数 $A$ は非負な值であることから, 簡単な相関式として式(B-5) と同様に $A=b N_{D}{ }^{a}$ とすれば，重み付 き残差二乗和は次式によって表される。

$$
S_{D}=\sum_{j=1}^{n_{D}} w_{j}\left(\log A_{j}-a \log N_{D, j}-\log b\right)^{2}
$$

したがって，最小条件 $\left(\partial S_{D} / \partial a=0, \partial S_{D} / \partial b=0\right)$ より正規方程 式が得られ, それを解けば $a$ および $b$ が次式のように求められる。

$$
A=83 N_{D}{ }^{-0.37}
$$

ここで, 大口径管エアリフトポンプの揚水特性について, 式 (27b) および式 (B-5) を用いた計算結果と実験值との比較の一例を示せ ば，Fig. A2 のとおりである。同図に示されるように式 (27b)によ る計算結果が実験値とよい一致を見ている。ただし，大口径管に おける摩擦損失の実験結果を含めた係数 $A$ の相関式については 今後の課題であろう。

付録 C 大口径管の助走域における気泡流および球冠状気泡流 の分布パラメータ $C_{G 0}$ に対して次式が提示されている ${ }^{16,17)}$ 。

助走域における気泡流に対して：

$0 \leq J_{G}^{+} / J_{M}^{+} \leq 0.9$ の場合；

$C_{G 0, B}=C_{B 1}-\left(C_{B 1}-1\right) \sqrt{\rho_{G} / \rho_{L}}$

$0.9 \leq J_{G}^{+} / J_{M}^{+} \leq 1$ の場合;

$C_{G 0, B}=\left(4.08-C_{B 2}\right)-\left(3.08-C_{B 2}\right) \sqrt{\rho_{G} / \rho_{L}}$

ここに,

$C_{B 1}=\exp \left\{0.475\left(J_{G}^{+} / J_{M}^{+}\right)^{1.69}\right\}$

$C_{B 2}=2.88\left(J_{G}^{+} / J_{M}^{+}\right)$

$J_{G}^{+}=J_{G} / V_{K U}$

$J_{M}^{+}=J_{M} / V_{K U}$

助走域における球冠状気泡流に対して:

$0 \leq J_{M}^{+} \leq 1.8$ の場合 ;

$C_{G 0, I}=C_{S 1}-\left(C_{S 1}-1\right) \sqrt{\rho_{G} / \rho_{L}}$

\begin{tabular}{|c|c|c|c|c|c|}
\hline Worker & $D[\mathrm{~m}]$ & $N_{D}$ & $A$ & $n_{A}$ & $w$ \\
\hline Toda et al. ${ }^{30)}$ & 0.0183 & 6.8 & 33.4 & 27 & 0.0597 \\
\hline Iinoya $^{32)}$ & 0.022 & 8.1 & 36.1 & 56 & 0.1239 \\
\hline Shiba et al. ${ }^{33)}$ & 0.025 & 9.2 & 49.5 & 50 & 0.1106 \\
\hline Hatakeyama et al. ${ }^{23)}$ & 0.0300 & 11.1 & 32.5 & 153 & 0.3385 \\
\hline Toda et ll. $^{30)}$ & 0.0303 & 11.2 & 38.5 & 40 & 0.0885 \\
\hline Usami et $a l_{.}^{31)}$ & 0.0465 & 17.2 & 28.6 & 126 & 0.2788 \\
\hline
\end{tabular}

Table A1 Parameters of Lockhart-Martinelli method in vertical two-phase flow.

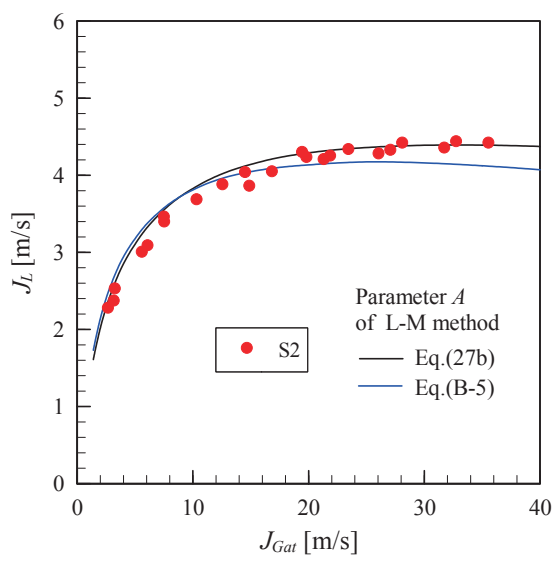

Fig.A2 Effect of parameter A of Lockhart-Martinelli method on volumetric flux of lifting water.

$1.8 \leq J_{M}^{+}$の場合 ;

$C_{G 0, I}=\left(1.2+C_{S 2}\right)-\left(0.2+C_{S 2}\right) \sqrt{\rho_{G} / \rho_{L}}$ ここに,

$C_{S 1}=1.2 \exp \left\{0.110\left(J_{M}^{+}\right)^{2.22}\right\}$

$C_{S 2}=0.6 \exp \left\{-1.2\left(J_{M}^{+}-1.8\right)\right\}$

また, 大口径管の助走域における気泡流および球冠状気泡流の無 次元気体体積率加重断面平均ドリフト速度 $V_{G j}^{+}$に対しては次式が 提示されている ${ }^{16,17)}$

$V_{G j, B I}^{+}=V_{G j, B}^{+} \exp \left(-1.39 J_{G}^{+}\right)+V_{G j, I}^{+}\left\{1-\exp \left(-1.39 J_{G}^{+}\right)\right\} \cdots$

なお，この場合の重み係数は次式によって与えられる。

$w_{f, B I}=w_{f, B}+w_{f, I}$

付録D 前報 6,7,11-13) においては，分布パラメータに対して, 流動様式に関わらず次式を用いている。

$C_{G 0}=1.2-0.2 \exp \left(-2.5 f_{G}\right)$

また, 無次元気体体積率加重断面平均ドリフト速度に対しては次 式を用いている。

気泡流に対して;

$V_{G j, B}^{+}=1.41\left(1-f_{G}\right)^{1.5}$

間欠流 (スラグ流・団塊波流)に対して；

$V_{G j, I}^{+}=\frac{0.35}{V_{K U}} \sqrt{\frac{g D \Delta \rho}{\rho_{L}}}$

上式は無次元管径 $N_{D}$ を用いれば, 次式のように簡潔に表される。 


$$
V_{G j, I}^{+}=0.35 \sqrt{N_{D}}
$$

付録E 壁面せん断応力に対して赤川 ${ }^{24)}$ および勝原 ${ }^{25)}$ は次式 を提示している。

$$
\frac{4 \tau_{W}}{D}=\frac{\Delta P_{L 0}}{\Delta z}\left(1-f_{G}\right)^{-1.75}
$$

\section{主な記号}

A : Lockhart-Martinelli 法における係数

$C_{G 0}:$ 分布パラメータ

$D$ : 管径

$f \quad$ : 体積率

$g \quad$ : 重力加速度

$J \quad$ : 体積流束

$L_{L} \quad$ : 空気注入口から出口までのエアリフト管長

$L_{O} \quad$ : 水面からから出口までのエアリフト管長

$L_{U}:$ 吸込口から空気注入口までのエアリフト管長

$l_{C} \quad:$ 式(13)で定義される特性長さ

$N_{D}$ : 無次元管径

$N_{\mu} \quad$ : 無次元粘度

$n \quad:$ 格子分割数

$P$ : 圧力

$P^{*} \quad$ : 静圧勾配

$P_{A}^{*}:$ 加速損失勾配

$P_{F}^{*}$ : 摩擦損失勾配

$P_{H}{ }^{*}:$ 位置損失勾配

$\Delta P$ : 圧力損失

$Q$ : 体積流量

$R e$ : レイノルズ数

$V$ : 平均速度

$V_{G j}$ : 気体体積率加重断面平均ドリフト速度

$V_{G j}^{+}$: 無次元気体体積率加重断面平均ドリフト速度

$V_{G j}^{*}:$ 平均ドリフト速度

$V_{K U}:$ 式 (16) で定義される特性速度

$V_{M}$ : 質量中心速度

$w_{f}:$ : 補間の重み係数

$z \quad$ : 流動方向の座標

$z^{\prime} \quad$ : 出口からの距離 $\left(z^{\prime}=L_{T}-z\right)$

$\Delta z \quad$ : 格子の大きさ

$\zeta$ : 圧力損失係数

$\theta \quad$ : 管路の局所傾斜角

$\lambda$ : 管摩擦係数

$[-]$

$\left[\mathrm{m} / \mathrm{s}^{2}\right]$

$[\mathrm{m} / \mathrm{s}]$

$[\mathrm{m}]$

$[\mathrm{m}]$

[m]

$[\mathrm{m}]$

$[\mathrm{Pa}]$

$[\mathrm{Pa} / \mathrm{m}]$

$[\mathrm{Pa} / \mathrm{m}]$

$[\mathrm{Pa} / \mathrm{m}]$

$[\mathrm{Pa} / \mathrm{m}]$

[Pa]

$\left[\mathrm{m}^{3} / \mathrm{min}\right]$

$[\mathrm{m} / \mathrm{s}]$

$[\mathrm{m} / \mathrm{s}]$

$[\mathrm{m} / \mathrm{s}]$

$[\mathrm{m} / \mathrm{s}]$

$[\mathrm{m} / \mathrm{s}]$ $\mu \quad$ : 粘性係数

$[\mathrm{Pa} \cdot \mathrm{s}]$

$\xi \quad$ : 助走損失係数

$\rho \quad:$ 密度

$\left[\mathrm{kg} / \mathrm{m}^{3}\right]$

$\sigma$ : 表面張力

$[\mathrm{Pa} / \mathrm{m}]$

$\tau_{W}$ : 壁面せん断応力

$[\mathrm{Pa}]$

添字 $A$ : 環状流, $a i$ : 空気注入口, at: 大気, $B$ : 気泡流, $I$ : 間欠流, $i n$ : 吸込口, $G$ : 気相, $M:$ 混合体, $L$ : 液相, out: 出口

\section{References}

1) Administration Office of the Headquarters for Ocean Policy: Basic Plan on Ocean Policy (April 2013), http://www.kantei.go.jp/jp/singi/kaiyou/kihonkeikaku/130426kihonkeikaku_ e.pdf.

2) M. Ishii: Argonne National Lab. Report (1977), ANL-77-47.

3) N. Hatakeyama and T. Masuyama: Journal of MMIJ, 107 (1991), 22-29.

4) S.V. Patankar: Numerical Heat Transfer and Fluid Flow, (Hemisphere, USA, 1980), pp.41-

5. Hatakeyama and T. Masuyama: Journal of MMJ, 105 (1989), 1051-1057.

6) N. Hatakeyama and T. Masuyama: Journal of MMIJ, 111 (1995), 471-476.

7) N. Hatakeyama, H. Takahashi, T. Saito and T. Masuyama: Journal of MMIJ, 114 (1998), 415-420.

M. Weber and Y. Dedegil: Hydrotransport 4 (1976), H1 1-24

9) T. Saito, et al.: Mining and Safety, 32 (1986), 540-551.

10) N. Hatakeyama, H. Takahashi, T. Saito and T. Masuyama: Journal of MMIJ, 113 (1997), $22-$ 28 .

11) N. Hatakeyama, H. Takahashi, T. Saito and T. Masuyama: Journal of MMIJ, 113 (1997), 333-338.

12) N. Hatakeyama, H. Takahashi, T. Saito and T. Masuyama: Journal of MMIJ, 115 (1999), 437-442.

13) N. Hatakeyama, H. Takahashi, T. Saito and T. Masuyama: Journal of MMIJ, 115 (1999), 958-964.

14) I. Kataoka and M. Ishii: Int. J. Heat Mass Transfer, 30 (1987), 1927-1939.

15) T. Hibiki and M. Ishii: Int. J. Heat Mass Transfer, 45 (2002), 707-721.

16) T. Hibiki and M. Ishii: Int. J. Heat Mass Transfer, 46 (2003), 1773-1790.

17) M. Ishii and T. Hibiki: Thermo-Fluid Dynamics of Two-Phase Flow (2nd Edition), (Springer, New York, 2011), pp.397-436.

18) T. Yoshinaga, Y. Sato and M. Sadatomi: Japanese J. Multiphase Flow, 4 (1990), 174-191.

19) T. Usami and N. Yamakado: Journal of MMIJ, 97 (1981), 245-250.

20) T. Usami, T. Saito and R. Kitahara: Journal of MMIJ, 98 (1982), 29-34.

21) N. I. Kolev: Multiphase Flow Dynamics 2 (3rd Edition), (Springer-Verlag, Berlin Heidelberg, 2007), pp.109-134.

22) N. Hatakeyama and T. Masuyama: Japanese J. Multiphase Flow, 8 (1994), 14-23.

23) N. Hatakeyama and T. Masuyama: Journal of MMIJ, 111 (1995), 465-470.

24) K. Akagawa: Trans. JSME, 23 (1957), 292-298.

25) T. Katsuhara: Trans. JSME, 24 (1958), 1050-1056.

26) A. Tomiyama, N. Furutani, H. Minagawa and T. Sakaguchi: Japanese J. Multiphase Flow, 6 (1992), 173-188

27) T. Kajishima and T. Saito: Trans. JSME (Ser.B), 60 (1994), 4125-4131.

28）宇佐美毅：エアリフトポンプによる固体粒子の輸送に関する研究,（博士論文,東 北大学, 1985).

29) T. Saito, Y. Tomishima, T. Yamazaki and T. Usami: Proc. MMIJ Annual Meeting (1987), pp.337-338.

30) M. Toda, E. Harada, M. Kuriyama, S. Saruta and H. Konno: Kagaku Kogaku Ronbunshu, 8 (1982), 380-386.

31) T. Usami and N. Yamakado: Mining and Safety, 23 (1977), 73-85.

32) K. Iinoya: Kikai no Kenkyu (Science of Machine), 10 (1958), 1007-1011.

33) M. Shiba and Y. Yamazaki: Trans. JSME, 32 (1966), 1231-1238. 